IJBE: Integrated Journal of Business and Economics

e-ISSN: 2549-3280

DOI: $10.33019 / \mathrm{ijbe} . v 2 \mathrm{i} 2.72$

Date of Publication: 4 June 2018

Volume 2 Issue 2, pp. 135-149

\title{
Dividend Omission Announcement Effect to Market Reaction in Indonesia Stock Exchange
}

\author{
Darmawan \\ UIN Sunan Kalijaga, Yogyakarta \\ darmawan@uin-suka.ac.id
}

\begin{abstract}
This study examined the signalling theory about how the market / investors respond to dividend announcements made by companies listed on the Indonesia Stock Exchange during the period 2008-2012. This period was chosen because the economy and economic growth of Indonesia is relatively stable. In general, the objective of this research is to develop new theoretical approaches, in an effort to resolve the conceptual controversies regarding the impact of dividend policy on firm value. That in detail, in particular, objective: To analyze and empirically test the market reaction to the announcement dividend omissions, as well as Analyze and test empirically the firm-specific characteristics variables that affect the market reaction. The samples are all companies that announced dividend policy for 5 years as many as 242 companies with 729 event announcements. The results showed that in events dividend announcement found a significant reaction from the market. At the announcement of dividend omissions, there are 5 significant observations with 2 observations fit in theory. The study also shows none of the significant characteristics of the company is able to explain the market reaction to dividend announcements.
\end{abstract}

Keywords: Characteristics of the Company, Dividend Omissions, Market Reactions

\section{Introduction}

In early 2013, the Indonesia Stock Exchange is seeking information from issuers who have not distributed dividends in the last three years, despite generating net profits (Atmaja, 2013). For example, PT Hero Supermarket Tbk (HERO) has not paid any dividend since its last dividend in 1996. Though HERO's net income grew well. And even in the third quarter of 2012, HERO's net profit reached Rp 222.02 billion, up 18.04\% year on year. Maybe Hero is inspired by Microsoft who just willing to pay dividends 17 years after going public. There is also PT Panorama Transportasi Tbk (WEHA) which for three years does not divide the dividend. Even in the next two years, WEHA plans not to share dividends. Management in information disclosure reasoned, need funds to increase the fleet (Indrasiti, 2013). 
IJBE: Integrated Journal of Business and Economics

e-ISSN: 2549-3280

Table 1 List of Number of Issuers Sharing Dividends

\begin{tabular}{lrrrrr}
\hline \multicolumn{1}{c}{ Information } & \multicolumn{5}{c}{ Year } \\
& 2008 & 2009 & 2010 & 2011 & 2012 \\
\hline Number of Issuers & 401 & 402 & 424 & 449 & 467 \\
Delisted & 6 & 12 & 1 & 5 & 4 \\
Sharing Dividend Cash & 171 & 179 & 207 & 231 & 218 \\
Percentage & 42.64 & 44.53 & 48.82 & 51.45 & 46.68 \\
\hline
\end{tabular}

Source: Data processing

Many issuers choose not to share the net income in the form of dividends. There are many reasons that issuers use to avoid dividend payouts (Fauzian, 2012). Starting from because it requires funds for expansion, until the obligation to pay the debt. Based on the data of Indonesia Stock Exchange there are seven issuers that have not yet want to give dividends. Even according to data Indonesia Stock Exchange data, in the past 10 years, there are at least 55 issuers who never share dividends to shareholders. (Merdeka.com, 2012). Currently, IDX is reviewing regulations that regulate the obligations of issuers to distribute dividends if they have experienced profits for at least two consecutive years (Koran Indonesia, May 4, 2013; NewsIDX, 2013; Indonesia Finance Today, 2013).

Table 2. List of Issuers that Never Share Dividends since the IPO

\begin{tabular}{ccc}
\hline No. & Issuer & IPO date \\
\hline 1. & PT Dyviacom Intrabumi Tbk (DNET) & December 11, 2000 \\
2. & PT Lippo Cikarang Tbk (LPCK) & July 24, 1997 \\
3. & PT Jakarta Kyoei Steel Works Tbk (JKSW) & August 6, 1997 \\
4. & PT Intikeramik Alamsari Industri Tbk (IKAI) & June 04, 1997 \\
5. & PT Eterindo Wahanatama Tbk (ETWA) & May 16, 1997 \\
\hline
\end{tabular}

Based on data from Indonesia Stock Exchange (IDX) listed at the beginning of 2013, there are already 44 issuers submitting the delay of dividend distribution for a financial report of 2012. Among them, PT Sarana Menara Nusantara Tbk (TOWR) will not pay a dividend for the 2010 and 2011 financial year period. (Neraca, January 31, 2013). In 2011, PT Sarana Menara Nusantara Tbk posted a consolidated profit before tax of Rp764 billion or grew $49 \%$ compared to the previous year. Rp1.1 trillion in revenues with Rp3.6 trillion in corporate loans and a cash balance of Rp 613 billion.

PT. Rukun Raharja Tbk (RAJA) which states will not share cash dividends for the period 20102011. The reason is that the company acquired PT Triguna Internusa Pratama and PT Panji Raya Alamindo in 2010. However, the company plans to distribute cash dividends at the closing of the fiscal year of 2012. In 2011, the company achieved a net profit of Rp16.1 billion. The company's revenue reached Rp796.7 billion, up 512\% from Rp155.7 billion in the previous year.

Satrio Utomo (IpotNews, 2012), said there are three reasons why issuers do not share dividends to their shareholders. First, the issuer is not profitable; secondly, because the company believes it 
can give higher shareholder returns from capital gains rather than returns in dividends; and thirdly, because the profits earned by the issuer come from the restructuring of its assets (financial engineering) and not because of its operational performance.

There are also categories of companies that never share dividends because the majority of investors do not need funds. Such as PT Schering Plow Indonesia Tbk (SCPI) and PT Bank Permata Tbk (BNLI). For Bank Permata, its majority shareholder, PT Astra International Tbk (ASII) and Standard Chartered Bank may not need fund from the dividend. The majority shareholders also prefer to dividend portion to enlarge the assets of Bank Permata.

\section{Literature Review}

According to Gordon (1959: 99), there are three possible hypotheses why an investor is willing to pay to own a number of company shares: dividends, capital gains and both. There are two scenarios of investors' attitude towards dividend payout. First, investors prefer dividends rather than capital gains. This is the investor type "A bird in the hand is worth two birds in the bush". That is, investors of this type are more appreciative of a more certain dividend than future risk capital at risk. This theory is known as the Brid in Hand Theory which was first introduced by M. J Gordon (1959: 99-105) and J. Lintner (1962: 243-269). Because retained earnings invested in new projects always involve risks. Very likely, retained earnings may be misused or invested in speculative projects, rather than being invested in prospective projects. Another reason is the payment of dividends that regularly discipline corporate management. The Bird in Hand Theory itself contradicts the Irrelevance of Dividend Policy Theory put forward by Merton H, Miller and Franco Modigliani (1961: 411-433), who say that dividend policy is irrelevant in affecting stock prices. This is confirmed by Gordon himself (1963: 264-272).

Second, investors prefer capital gains rather than dividends. The main reason is the tax on dividends is higher than the tax on capital gains. Thus, in accordance with the Tax Different Theory of Litzenberger and Ramaswamy $(1979 ; 1980 ; 1982)$, due to the tax on Dividends and capital gains. Investors prefer capital gains because they can delay paying taxes. According to the Income Tax Act 1984 amendment 2008, the dividend tax rate is 10\% and is final (Article 17 paragraph 2c).

In the context of the dividend policy that is done as the company's financial policy, Jogiyanto (2012: 237) questioned that in fact the companies in Indonesia no one throws sign dividend (signalling theory). For dividend policy intended with a signal to the capital market should be done as a long-term corporate policy that is connected with the company's ability to generate cash inflows to finance dividends. Thus dividend payout can be viewed as a signal of the company's ability to generate cash flow in the future and is a positive signal.

In looking at the dividend announcement there are two main theories, the first theory is irrelevant dividend theory which states that there is no effect of dividend policy on stock return. The second theory is dividend signalling theory which states that the announcement of the change of dividend payment has an important information content that can affect stock return. This is because dividend has a signal that can affect investor confidence that is reflected in stock prices. So, in general, there is a debate over how dividend policy affects stock prices or corporate value. 
The first opinion says that dividend policy is irrelevant, meaning that there is no optimal dividend policy because dividend policy does not affect company value. The second opinion says that dividends are less risky than capital gains, so it is advisable to increase dividends. While the third opinion says that the dividend tends to be taxed higher than the capital gain, so it is better the company determines the low dividend payout ratio or even not dividend at all to maximize the value of the company.

Finally, it must be said for a while that the inconsistency of the results of previous research on opinions questioning the dividend policy, should have its own confirmation. This can happen because of several things, such as lack of information or type, characteristics or time of research. Or at least it can be concluded that the opinions expressed reinforce the previously expressed opinion of at least three opinions on dividend policy in the perspective of signalling theory. In this study, the researcher will specialize the study on the dividend policy on companies listed on the Indonesian stock exchange.

\section{Hypotheses, Data and Methodology}

\section{Hypotheses}

Based on the literature mentioned, it is expected a positive relationship between Omission announcement effect to the market reaction in order to test this relationship to formulate the following hypotheses:

1. There is a positive influence of announcement of dividend omission to market reaction.

2. The market reaction to the omission dividend announcement supports the hypothesis of the market efficiency of the half-strong form.

3. Variable characteristics of the company able to explain the market reaction to the announcement of dividends omission

\section{Location, Population and Sample}

The population of this study are all companies listed on the Indonesia Stock Exchange. The sampling technique in this study using purposive sampling is taking samples based on certain criteria (Jogiyanto, 2010: 47-51). Criteria for sampling in this study are the Company that made the announcement of dividend omissions listed on the IDX that is as many as 79 companies in the period 2008 - 2012. This period was chosen because the economy and economic growth Indonesia is relatively stable. Companies that have financial reports on current assets, total assets, total debt, total equity, dividends per share, earnings per share and book value per share in the period of observation. With the total number of announcements examined over 5 years is 729 announcement events.

\section{Data analysis technique}

1. Event Study Procedures

The methodology of the study of conventional events follows the following procedures: Identify the form, effect and time of the event; Specifies the time range of the study of events including the estimation period and the event period; Determination method of return of market model used to calculate the abnormal return. The estimated period is required when the calculation of abnormal returns using statistical models and economic models; Calculates abnormal returns around the event period; Calculates abnormal averages and cumulative 
abnormal returns in the event period; Test whether the average abnormal return or cumulative abnormal return is different from 0 . Or is the abnormal return before the event differs from the return after the event.

2. Procedures for Market Efficiency Event Studies

At this stage, it is an event study to test the efficient market of a half-strong form. Efficient market testing is a continuation of information content testing (Jogianto, 2010: 171). If the information content test only tests an abnormal return as a market reaction, market efficiency testing continues by testing the rate of market reaction.

3. Procedure Analysis variable Company Characteristics

The next stage of the research is to test the 3rd hypothesis, namely to examine the effect of a corporate characteristic variable on a normal return (as a measure of shareholder reaction).

This sub-research is trying to explain the cause of further market reaction (Tandelilin, 2010:

236-239). This test is done by using cross-section model (Juanda, 2012: 144).

\section{Results and Discussion}

\section{First Hypothesis Testing}

After the identification process of qualifying the type of announcement events, and continued with the process of verifying the completeness of the data. The next step is to determine the estimated period and window period. Actual Return Data on the announcement event does not distribute this dividend obtained from 61 stocks studied. The results of data analysis on the announcement event do not distribute this dividend show the average of the actual Return:

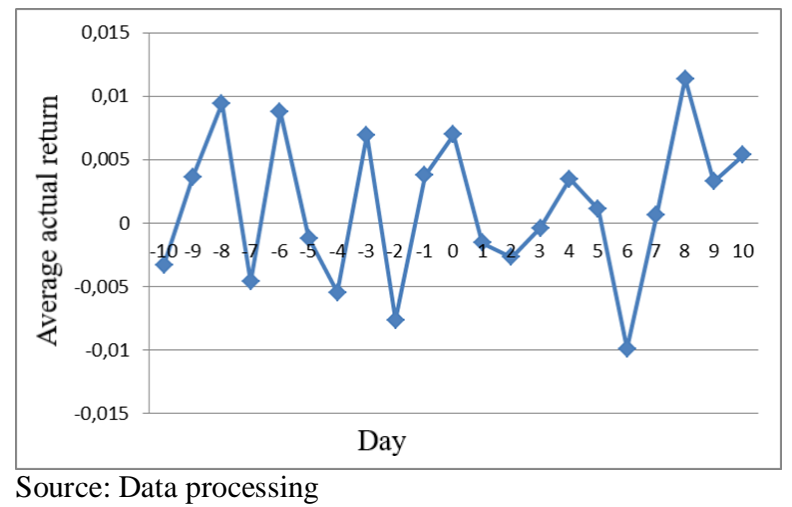

Figure 1. Average Actual Return of Dividend Omission Announcement

With the cumulative actual Return as follows: 


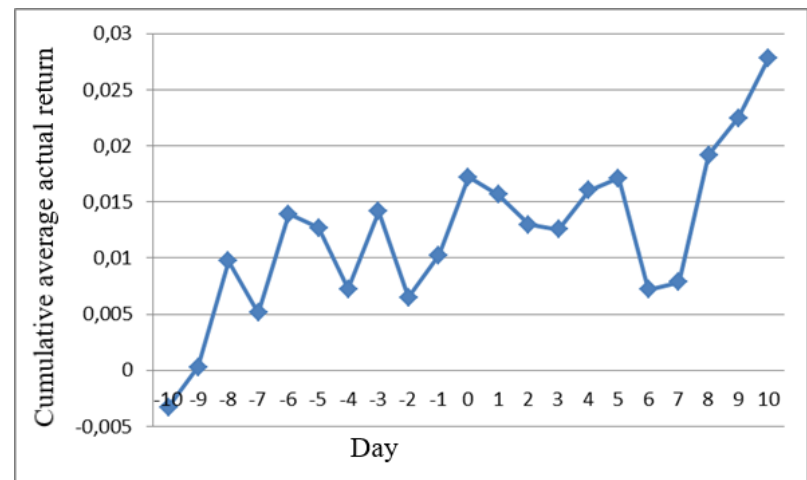

Source: Data processing

Figure 2. Cumulative Return Actual Dividend Omission Announcement

From the 61 research samples, there are 32 issuers that have an average actual return of negative stocks during the window period. While having an average Return of Actual positive shares of 25 issuers. And with an average actual return of zero, there are 4 issuers. At the time of the event day, there are 19 issuers that have the actual Return of negative stock while those who have the positive actual return of 21 emits. And the remaining 21 issuers have zero stock returns at the time of the event day.

Average Actual Return on Window Period

\section{Actual Return on Event Day}
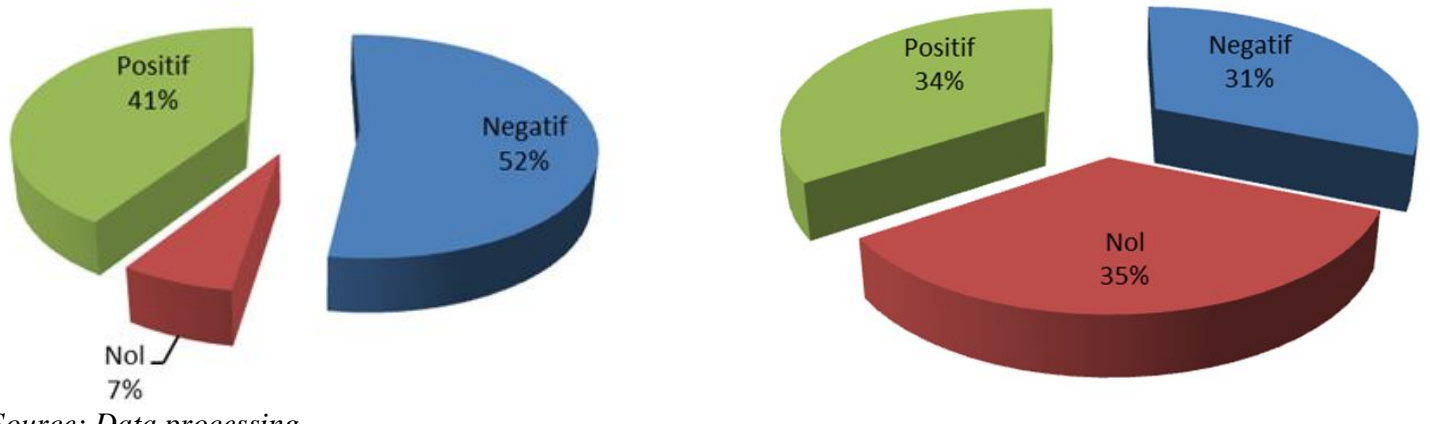

Source: Data processing

Figure 3. The proportion of Actual Return on Dividend Omission Announcement

In an attempt to predict $\mathrm{E}\left(\mathrm{R}_{\mathrm{it}}\right)$ based on the estimation of the market model over the estimation period with the model described as follows:

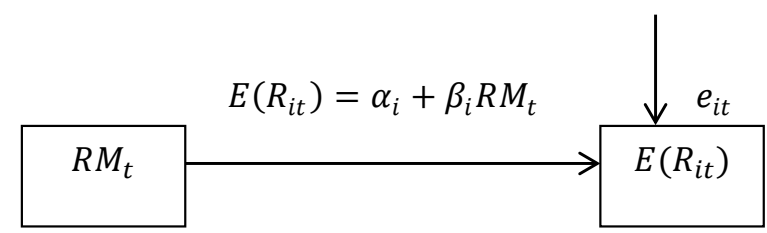

Figure 4. Estimation Model at Dividend Announcement Event

From the results of data validity test analysis, it can be said that all the instrument questions tested its validity. It can be seen from the value of $r$-value of each instrument of the question asked bigger than $r$ table value (0.1646) so that all question instrument can be used in this 
research. Instruments that have been tested the level of validity then will be tested the level of reliability. Reliability with regard to the level of reliability or determination of measurement results (Sukmadinata, 2009). Ghozali (2009) states that reliability is a tool to measure a questionnaire that is an indicator or a variable or constructs. The high level of reliability is indicated by the value of the reliability coefficient. Of the four variables used, the skill variable has an alpha value of 0.642 , which is categorized to moderate (moderate) reliability.

Based on the estimation of intercept and beta, the expected return calculation can be done by entering the market return (RM) for each sample into the market model. The result of abnormal return calculation is obtained by reducing the actual return with expected return on each observation $\left(\mathrm{RTN}_{\mathrm{it}}=\mathrm{R}_{\mathrm{it}}-\mathrm{E}\left(\mathrm{R}_{\mathrm{it}}\right)\right.$.

Abnormal Average Return and Abnormal Cumulative Average Return describes the average picture of abnormal returns in the window event period of omission dividend announcement can be seen in the following figure:

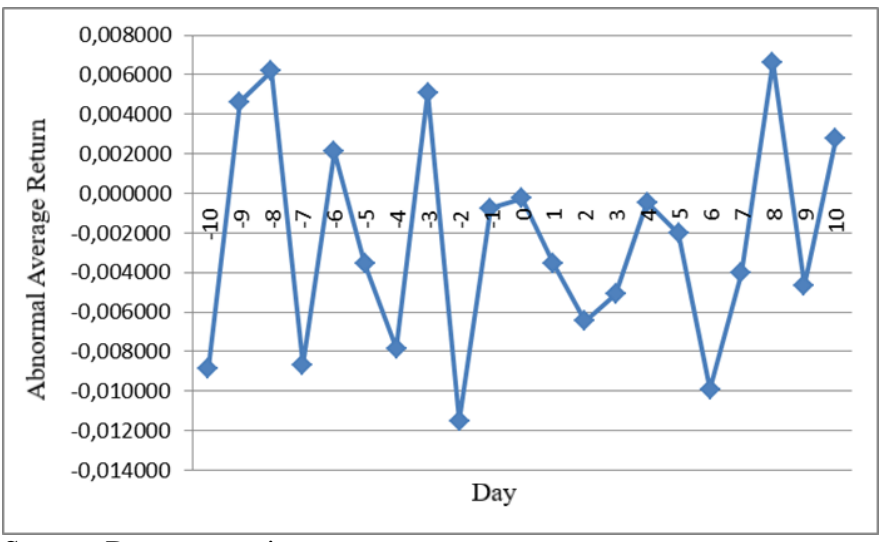

Source: Data processing

Figure 5. Abnormal Average Return on Dividend Omission Announcement Window Period

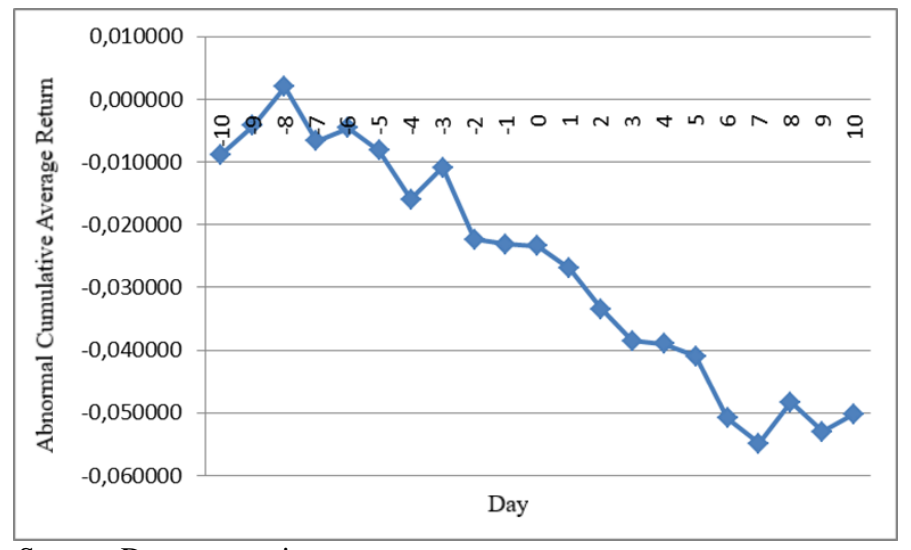

Source: Data processing

Figure 6. Abnormal Cumulative Average Return on Window Period Announcement Dividend Omission

The next stage is to test whether the average abnormal return or cumulative abnormal return is different from 0 , or whether the return is abnormal before the announcement of the division of 
the Omission dividend from the return after the event. Testing is done by t-test. To calculate standardized abnormal returns required Standard Error Value of securities estimation.

$$
\begin{gathered}
R T N S=\frac{R T N}{K S E(R T N)} \\
K S E_{i}=\sqrt{\frac{\sum_{j=1}^{t-n}\left(R_{i j}-\overline{R_{\imath}}\right)^{2}}{T-n-2}}
\end{gathered}
$$

The standard error of estimate is calculated by calculating the standard deviation of stock returns examined in the event of this dividend announcement. The standard error of estimate is calculated during the estimation period, i.e. $t-61$ to $t-11$. For the purpose of testing market reaction that supports signalling theory can be done by comparing $t$ arithmetic with KSE in table 3 below:

Table 3. Abnormal return Standardized and T-Test (Dividend Announcement)

No

Dividend Announcement

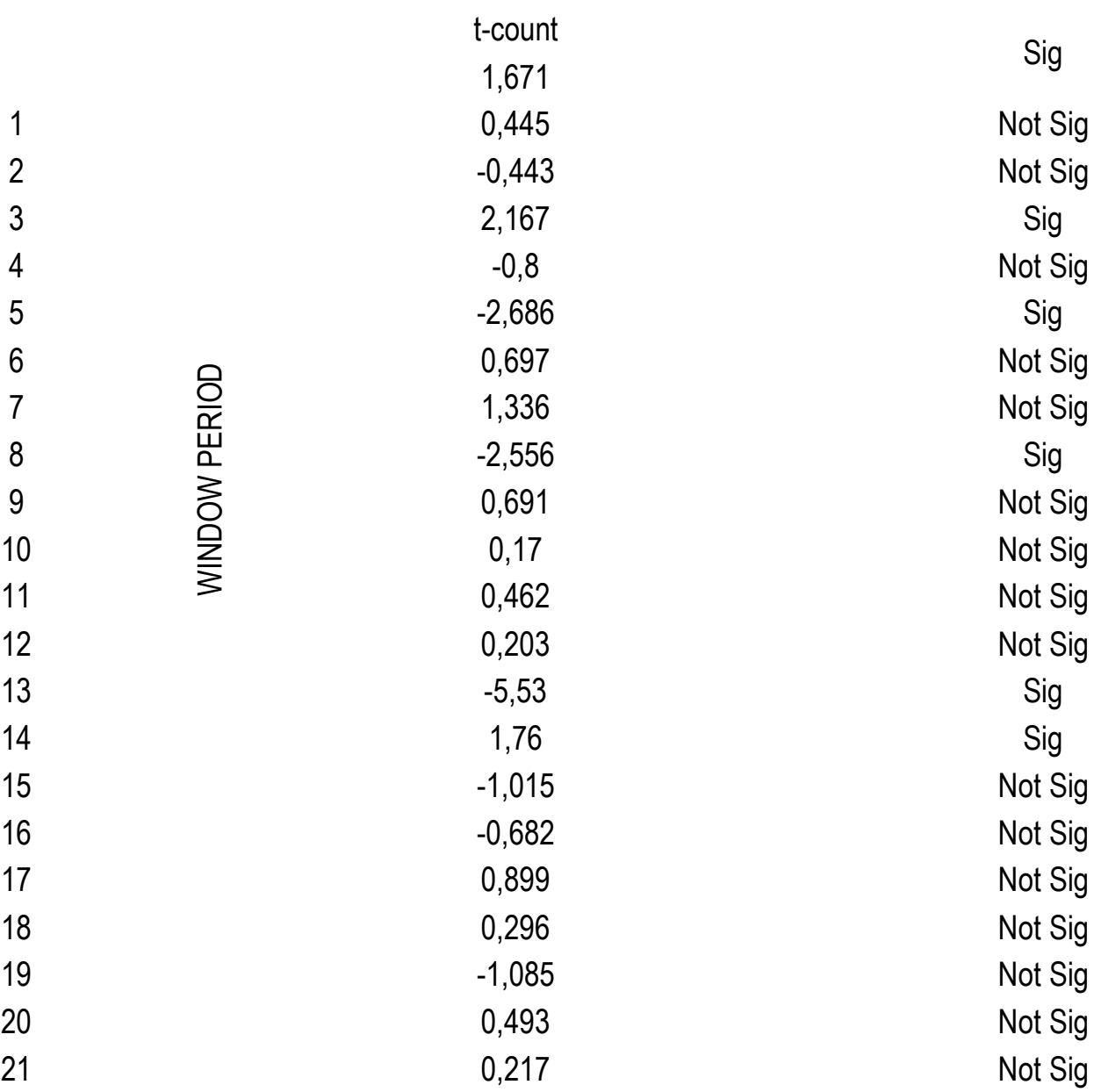


The result of calculation of RTNS and t-Test on Dividend Omission Announcement note that observation too $-3,-2,3,6$ and 8 proved significant.

\section{Second Hypothesis Testing}

The 3rd and 8th observations are contrary to the predictions of signalling theory, whereas the observations that provide other significant results match the predictions of signalling theory. In the case of policy announcement events not paying dividends in the fiscal year 2008 - 2012 it can be seen that there are 3 observations that are significant and accepted in theory. The result of ttest also shows that 1 observation before event day while 2 observations after event day.

The study of the announcement of a dividend of Azizah Ayu Sielvia's dividend (2009: 113-128) in the period 2004 - 2008 with 37 samples in Indonesia Stock Exchange shows the test result of $\mathrm{t}$-test with one sample t-test, showing that for day $\mathrm{t}-9$ and $\mathrm{t}+1$ proven abnormal return is negative and significant. As for the other days, there is no significant abnormal return. The findings on the Thai Stock Exchange, Kulkanya Napompech (2010: 1-8) said that the market reaction was not significant at the announcement of dividend omission on the Thailand Stock Exchange period 1994-2008 with 76 samples, because the market was able to anticipate the future state of the company. So the announcement of the dividend is not divisible is considered to contain no information.

With different angles Rajiv Sant and Arnold R. Cowan. (1994: 1113-1133) on the negative significance of market reaction to the Dividend Omission Announcement, said that the mechanism of signalling theory is used by managers to show uncertain future returns. Rajiv shows that after the announcement of dividend omission, the increased profit variability, in other words, indicates that future income is difficult to predict.

\section{Third Hypothesis Testing}

In this event dividend, announcement research proceeds to explain what variables cause this abnormal Return with a metric explanation. To explain the metrics of the abnormal Return which is a market reaction is also influenced by the company's specific characteristics, this study will use regression techniques.

Data processing will be done with the help of SPSS, with output table coefficient as follows:

Table 4. Regression Coefficient $\mathrm{CAR}=\mathrm{f}($ Company Characteristics $)$ at Dividend Omission Announcement

\begin{tabular}{|c|c|c|c|c|c|c|}
\hline & \multirow[t]{2}{*}{ Model } & \multicolumn{2}{|c|}{$\begin{array}{c}\text { Unstandardized } \\
\text { Coefficients }\end{array}$} & \multirow{2}{*}{$\begin{array}{c}\text { Standardized } \\
\text { Coefficients } \\
\text { Beta } \\
\end{array}$} & \multirow[t]{2}{*}{$\mathrm{t}$} & \multirow[t]{2}{*}{ Sig. } \\
\hline & & B & Std. Error & & & \\
\hline \multirow[t]{4}{*}{$\overline{1}$} & (Constant) &, 001 &, 282 & & ,002 & ,999 \\
\hline & DivYield & ,009 & ,007 &, 180 & 1,231 &, 224 \\
\hline & Size &,- 007 & ,013 &,- 097 &,- 558 & ,579 \\
\hline & Inst &, 149 &, 164 & , 137 & ,912 &, 366 \\
\hline
\end{tabular}


IJBE: Integrated Journal of Business and Economics

e-ISSN: 2549-3280

\begin{tabular}{cccccc}
\hline Beta &,- 017 &, 040 &,- 063 &,- 440 &, 662 \\
MBVE & 1,927 & 4,338 &, 071 &, 444 &, 659 \\
a. Dependent Variable: CAR & & & & & \\
\hline Soln
\end{tabular}

Source: Data processing

This output shows that the abnormal Return does not exist any significant variables with tcount $>$ t-table $(0,681)$ and sig $<\alpha(0,05)$ then it is not significant. So it can be concluded that the abnormal Return on the event of Dividend Omission Announcement in the fiscal year 2008 2012 cannot be explained all the characteristics of the company hypothesized on this research model.

\section{Discussion}

At Dividend Omission Announcement there are 3 observations that are significant and in accordance with the theory and occur time lag. So it also shows that the market is inefficient. This is in line with the results of Yulianto's research, Hans (1999) who found that In 1997 the condition of the Jakarta Stock Exchange did not include the market efficiency of the half-strong form. This suggests that changes in stock prices do not adequately reflect dividend announcement information, which means that markets react slowly indicated by market reactions several days after the announcement of dividends is made public. So concluded that dividend announcement is not good news for investors, dividend announcement information has not been received simultaneously by the investor, and Jakarta Stock Exchange reacts slowly to dividend announcement.

Doddy Setiawan \& Siti Subekti (2004) pointed out that the Testing of market efficiency in a halfrobust form of information includes testing of the information content of dividend announcements and market reaction speed. The results of this study show the announcement of dividends has information content, but investors react slowly. Based on this research, JSX during the period of monetary crisis has not been efficient yet half strong in information. The results of testing the accuracy of market reaction show investors react positively to the announcement of increased dividends grow and not grow. Investors have not been sophisticated in response to the increased dividend announcement submitted by issuers. In general, investors perceive dividend announcements to increase as good news, so they do not process the information further. Based on these results, it can be concluded that the Indonesian capital market during the monetary crisis has not been efficiently half-strong by decision. The result of this research is consistent with the research of Sujoko (1999) and Setiawan and Hartono (2003) that JSX is not efficient yet half strong decision.

As outlined in the Bapepam (2011) Team, there are several factors that allegedly contributed to market inefficiencies, such as the low level of liquidity and the openness of Issuers in disclosing the actual information. Furthermore, Sukamulja (in Team Bapepam, 2011) suggests some conditions of investors in the Indonesian capital market that may contribute to the weakness of market efficiency, including:

1. Investors have information that is not symmetrical;

2. Investors tend to be irrational in making decisions, among them due to inadequate knowledge;

3. Investors often overreact to a recent development; 
4. Investors are less likely to follow the concept of capital market investment (for example, considering risks and returns and investing for the long-term).

The results of this study indicate no significant dividend yield in affecting the magnitude of abnormal return on dividend announcement, in accordance with research conducted by Christian Andreas at., Al. (2009: 26-27). Christian examined the cumulative abnormal return of 16 industrial samples in Germany. This according to Christian in accordance with previous findings that the dividend yield does not have the power to explain if the regression equation based on market expectations.

But contrary to the results of research Pradipta Castle (2011: 40) which concluded that the effect of dividend yields significant to cumulative abnormal return. The study was conducted on dividend policy and debt policy at company growth rate at non-bank companies listing in Indonesia Stock Exchange in 2004-2008.

The results of this study indicate no significant size, reinforced by research studies Semra Karacaer and Pelin Ozek, (2009: 156-162) to 65 companies that announced dividends on the Turkish Stock Exchange, Istanbul Stock Exchange, in the period 2003-2007 showed the significance of the influence of dividend yield against abnormal return. These results are in contrast to findings of Christian Andreas at., Al. (2009: 26-27). Who found that in Germany, Size affects the magnitude of abnormal returns on dividend announcements negatively.

The results of this study indicate no significant institutional ownership of abnormal return, in line with this study Ni Luh Putu Wiagustini, et al. (2012: 123-124) found that Institutional Ownership has no significant effect on Stock Price. This means that the large or small share ownership by institutions at manufacturing companies in the Stock Exchange did not have a direct impact on changes in Stock Price.

This indication of institutional ownership is also put forward by Christian Andreas at., Al. (2009: 26-27) which discloses the study of dividend announcements in Germany, a country that has an institutional setting and a capital market environment that is substantively different from the United States and Britain. In mainland Europe, like Germany, found the characteristic of concentrated ownership and the weakness of protection of minority ownership. In addition to the conflict of interest between owners and managers, there is also an empirical fact of conflict of interest between large blockholders and minority shareholders in concentrated ownership of shares, exactly the same as the empirical facts found in Indonesia.

The results of this study indicate no significant beta effect, in contrast to the results of research Gosh and Woolridge (1988) conducted research on market reaction to dividend cut / omission and using multiple regression model to determine the effect of previous stock performance, Find empirical evidence that the market reacted negatively to the announcement of dividends of omissions and influenced by the performance of shares before the announcement. The same results found a beta effect on the dividend announcement studied by Rajiv Sant and Arnold R. Cowan (1994: 1113-1133). Rajiv studied 381 omissions, based on the Wall Street Journal Index for the news of the omission announcements of the period 1963-1986. This GW opinion is 
reinforced by his research Below, and Jhonson (1996: 15-26) which mentions Beta can be interpreted as a measure of future stock price movements expected by the market. As a result, he argued that a high beta would react more to a lower dividend than a low beta of stocks, as a decrease in stocks in high beta stocks could signal that pessimistic management about the prospects of cash flow or stock prices around this dividend policy period. So beta has a negative coefficient on the dividend decrease. While on the announcement of a dividend increase in high stock beta must be seen little reaction than low stock beta.

The results of this study indicate no significant Market Book Value to Equity influence; this is in line with findings Cecilia Triana (2012: 123) that indirect influence of Set Opportunity of Investment (MBVE) to Share Price through Dividend Policy is not a significant effect. The research was conducted at a manufacturing company listed on Indonesia Stock Exchange during 2006-2008. Sampling was done by using purposive sampling technique with criteria of all manufacturing companies in Indonesia Stock Exchange (IDX) which distributed cash dividend continuously during the 2006-2008 period and has complete financial report data for the period 2006-2008.

Companies with high growth rates mean having many investment opportunities. Funds that should be paid as cash dividends to shareholders will be used for the purchase of profitable investments, even to address underinvestment issues. Companies that experience slow growth tend to pay higher dividends to overcome the problem of overinvestment.

\section{Conclusion, Suggestions, and Recommendations}

\section{Conclusions}

a. The policy announcement does not distribute dividends reacted by the market which is reflected in the form of abnormal returns proved to be significant that dividends contain information.

b. At the Dividend Omission Announcement, there are 5 significant observations with 2 observations prior to the announcement with the corresponding alignment of signalling theories; 3 observations after the announcement and also mixed with 2 according to theory and 1 is not appropriate. This shows the market is not efficient and shows a variety of perceptions. So based on the analysis of the announcement of this dividend can be concluded that the Indonesia Stock Exchange does not support the hypothesis of a form of half-strong market.

c. At the Dividend Omission Announcement, there are no single characteristics of the firm that can explain the market reaction.

\section{Suggestions}

a. Based on the findings on the insignificant effect of institutional share ownership (Inst) on abnormal return. In subsequent research, it is deemed necessary first to separate the possibility of finding the characteristics of concentrated ownership and the weak protection of minority ownership. So it can be more clear on the characteristics where the actual institutional share ownership significantly influences the abnormal return on the announcement of this dividend. 
b. Based on the findings on the non-significant effect of investment opportunity (Market to Book Value Equity) on abnormal return. In the next study suggested that companies separated first based on Return on Investmentnya for sample data will be separately analyzed between those who have an active investment trend with good profits and not. So that will avoid the apparent price movement that may get in Market to Book Value Equity, for research in understanding MBVE and its influence to stock price movement and its return not be biased.

c. Investors in analyzing are not enough to just make observations on charts of stock trading but must also do fundamental analysis. This will keep investors away from losses due to an interest in stock price increases when the company's performance is reduced, allowing the company to go bankrupt in the future.

d. For further researchers, who are interested in conducting further research in an attempt to understand the market reaction to the dividend announcement can include the ratios of the company's financial performance. It is also essential to research the market reaction on the interim dividend announcement, since this announcement can more easily sort out possible confounding events at the GMS as well as the replacement of directors, earnings announcements, etc. Of course, the context is no longer the issue of rising and falling dividends, but rather the content of other information in dividend policy.

\section{Recommendations}

a. The market reaction as shown by the results of this study proves that in principle the investor calculates the amount of dividend yield as well as capital gain (loss). So the indication of the Regulator on the Indonesia Stock Exchange that the BEI is reviewing the regulations that regulate the obligations of issuers to distribute dividends if it has experienced profits at least in 2 consecutive years is in accordance with market desires.

b. Based on the findings of indication of the possibility of information leakage at the event of dividend announcement that allows unauthorized profit is taking through insider trading, the regulator in Indonesia Stock Exchange should further tighten the possibility of this crime and give appropriate action to the perpetrators.

c. Based on the findings on the insignificant effect of institutional share ownership on the stock price (cumulative abnormal return), it is suggested that industrial companies in IDX need to increase public ownership held by the public so that the ownership of stock is more spread and not concentrated on certain families as the majority shareholder.

\section{References}

1) Atmaja, Lukas Setia, (2013). Dividen: Emang Gua Pikirin. Kontan Online. 4 Februari 2013 (22:04)

2) Azizah Ayu Sielvia. (2009). Pengaruh Dividen Inisiasi Dan Dividen Omisi Terhadap Return Saham Di Bursa Efek Indonesia. Jurnal Siasat Bisnis Vol. 13 No. 2, Agustus 2009 Hal: 113-128.

3) Cecilia Triana, dkk (2012). Variabel-Variabel Yang Berpengaruh Terhadap Kebijakan Dividen Serta Harga Saham Pada Perusahaan Manufaktur Di Bursa Efek Indonesia. Jurnal Manajemen, Strategi Bisnis, dan Kewirausahaan Vol. 6, No. 2 Agustus 2012.

4) Doddy Setiawan \& Siti Subekti. (2004) Pengujian Efisiensi Pasar Bentuk Setengah Kuat Secara Keputusan: Analisis Pengumuman Dividen Meningkat (Studi Empiris pada Bursa Efek Jakarta Selama Krisis Moneter).Jurnal RIDXt Akuntansi Indonesia 7. 
IJBE: Integrated Journal of Business and Economics

e-ISSN: 2549-3280

5) Fauzian, R, (2013). Dirut BEI: Tak Bagi Dividen, Emiten Pasti Punya Alasan. OkeZone. 31 Januari 2013. (13:33)

6) Gordon, M.J, (1963). Management of Corporate Capital: Optimal Investment and Financing Policy. The Journal of Finance, vol. 18, No. 2 (May, 1963), 264-272.

7) Gordon, M.J., (1959). Dividends, Earnings, and Stock Prices. The Review of Economics and Statistics, Vol. 41, No. 2, Part 1 (May 1959), 99-105.

8) Indrastiti, N., (2013). BEI Bakal Atur Emiten Tak Bagi Dividen. Kontan Online. 1 Februari 2013. (06:08)

9) Jogiyanto, (2010). Metodologi Penelitian Bisnis : Salah Kaprah dan Pengalaman-Pengalaman, Badan Penerbit BPFE Yogyakarta.

10) Kulkanya Napompech. (2010). Earnings Information Conveyed By Dividend Policy. King Mongkut's Institute of Technology, Ladkrabang, Thailand.

11) Lintner, John, (1962). Dividends, earning, leverage, stock price, and the supply of capital to corporations. Review of Economics and Statistics, 44. Hal $243-269$.

12) Litzenberger, Robert H dan Ramaswamy, (1979). The Effect of Personal Taxes and Dividends on Capital Assets Prices: Theory and Empirical Evidence. Journal of Financial Economics. Vol 7, Issue 2 (June 1979), 163-195.

13) Litzenberger, Robert H dan Ramaswamy, (1980). Dividends, Short Selling Restrictions, Tax-Induced Investor Clienteles and Market Equilibrium. The Journal of Finance. Vol. 35, Issue 2 (May 1980), 469-482.

14) Litzenberger, Robert H dan Ramaswamy, (1982). The Effects of Dividend on Common Stock Prices: Tax Effect or Information Effects? The Journal of Finance. Vol. 37, No 2 (May 1982), 429-443.

15) Miller, Merton H dan Modigliani, Franco, (1961). Dividend Policy, Growth, and the Valuation of Shares. The Journal of Business, vol 34, No. 4 (Okt., 1961), 411-433.

16) Ni Luh Putu Wiagustini, dkk., (2012). Variabel-Variabel Yang Berpengaruh Terhadap Kebijakan Dividen Serta Harga Saham Pada Perusahaan Manufaktur Di Bursa Efek Indonesia. Jurnal Manajemen, Strategi Bisnis, dan Kewirausahaan Vol. 6, No. 2 Agustus 2012.

17) Pradipta Puri, (2011). Pengaruh Investment Opportunity Set, Kebijakan Deviden Dan Kebijakan Hutang Perusahaan Terhadap Harga Saham (CAR). Pada Perusahaan Non-Bank Yang Listing Di Bursa Efek Indonesia Pada Tahun 2004-2008. Unila.

18) Rajiv Sant dan Arnold R. Cowan. (1994). Do Dividends Signal Earnings? The Case Of Omitted Dividends. Journal of Banking and Finance, 1994, v18 \#6, 1113-1133.

19) Scott D. Below dan Keith H. Johnson. (1996). An Analysis Of Shareholder Reaction To Dividend Announcements In Bull And Bear Markets. Journal Of Financial And Strategic Decisions. Volume 9 Number 3, Fall 1996.

20) Semra Karacaer dan Pelin Ozek, (2009). How do firm characteristics affect the market reaction to investment announcements: IDX case. Investment Management and Financial Innovations, Volume 6, Issue 1, 2009.

21) Setiawan, Doddy dan Jogiyanto, (2002). Pengujian Efisiensi Pasar Bentuk Setengah Kuat Secara Keputusan : Analisis Pengumuman Dividen Meningkat, SNA 5, 334-347

22) Tim Studi Volatilitas Pasar Modal Indonesia dan Perekonomian Dunia. (2011) Volatilitas Pasar Modal Indonesia Dan Perekonomian Dunia. BAPEPAM, KEMENKEU.

23) Yulianto, Hans.(1999) Analisis Pengaruh Pengumuman Deviden Terhadap Return Saham Dan Efisiensi Pasar Modal (Studi Kasus Perusahaan Manufaktur Di Bursa Efek Jakarta Tahun 1997). Universitas Diponegoro.

24) Indonesia Finance Today, (2013). Bursa Bakal Wajibkan Emiten Bayar Dividen. 31 Januari 2013. (14:00)

25) Koran Indonesia, (2013). Untung 2 tahun, Emiten Harus Bagi Dividen. 22 Februari 2013, Hal 11-12. 
IJBE: Integrated Journal of Business and Economics e-ISSN: 2549-3280

26) IpotNews, (2012). Selama Lebih Dari 10 Tahun, 55 Emiten Ogah Bagikan Dividen. http://indopremirenews. wordpress.com. 27 November 2012. (22:35)

27) Merdeka.com., (2012). Selama 10 tahun, 55 Emiten Tak Pernah Bagi Dividen. Senin, 26 November 2012. (19:31)

28) Neraca, (2013). Tutup buku, Tren Emiten Pelit Dividen Kembali Marak. 31 Januari 2013.

29) NewsIDX, (2013). Bursa Akan Atur Emiten Yang Tak Bagi Dividen. 1 Februari 2013. http://www.newsidx.com (08:00) 